\title{
Boceprevir (BOC) and Telaprevir (TPV) therapeutic drug monitoring in HCV and HIV-HCV infected patients treated with triple therapy Ribavirine/ Peg-interferon/Boceprevir or Telaprevir: impact of the antiretroviral (ARV) treatment
}

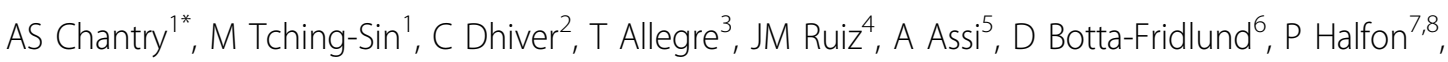 \\ O Faucher-Zaegel ${ }^{9}$, C Solas ${ }^{1,10}$
}

From International Symposium HIV and Emerging Infectious Diseases 2014

Marseille, France. 21-23 May 2013

\section{Introduction}

BOC and TPV are potent NS3/4A protease inhibitors for the treatment of chronic hepatitis $\mathrm{C}(\mathrm{HCV})$ genotype 1 infection. BOC and TPV are both substrates and strong inhibitors of the CYP3A, therefore presenting a wide interindividual pharmacokinetic variability and multiple drug interactions especially with ARV such as lopinavir/r, darunavir/ $\mathrm{r}$ or efavirenz, thus restricting options for concomitant ARV therapy. We evaluated plasma concentrations of coinfected and monoinfected patients treated with BOC and TPV and the PK data of patients treated with non recommended ARV.

\section{Method}

Data from patients whose BOC and TPV trough concentration had been assessed during treatment were retrospectively analyzed. Plasma concentrations were determined using a LC-MS/MS method. Mann-Whitney U test was used for statistics (PASW Statistics 17).

\section{Results}

Overall, 58 patients were included ( $84 \%$ male, median age: 51 years (34-70)), treated with BOC (25) or TPV (33). Thirty-two (55\%) patients are coinfected (14 BOC, $18 \mathrm{TPV}$ ) and 26 (45\%) are monoinfected (11 BOC, 15 TPV). Median (range, CV) TPV and BOC trough

${ }^{1}$ Timone Hospital, Pharmacokinetics and toxicology department, Marseille, France

Full list of author information is available at the end of the article concentrations were respectively, $1928 \mathrm{ng} / \mathrm{mL}$ (92-3204, $47 \%)$ and $111 \mathrm{ng} / \mathrm{mL}(33-903,112 \%)$ in coinfected patients versus $2787 \mathrm{ng} / \mathrm{mL}(252-5551,54 \%)$ and $153 \mathrm{ng} / \mathrm{mL}(25-2658,150 \%)$ in monoinfected patients, which is statistically different only for TPV $(p<0.05)$. Six patients received non recommended ARV: 4 were treated with darunavir/r (2 BOC, 2 TPV), 1 with efavirenz and BOC and 1 with lopinavir/r and TPV. Median (range) TPV and BOC concentrations were respectively, $1967 \mathrm{ng} / \mathrm{mL}$ (580-3204) and $103 \mathrm{ng} / \mathrm{ml}$ (33-903) with recommended ARV versus $1304 \mathrm{ng} / \mathrm{mL}(92-2565)$ and $146 \mathrm{ng} / \mathrm{ml}$ (65-304) with non recommended ARV.

\section{Conclusion}

This study highlights a strong interindividual variability in BOC and TPV trough concentrations. Lower concentrations were observed in coinfected patients but remaining within the expected range, which may be explained by drug interactions with some ARV. Hence, therapeutic drug monitoring is useful to manage these interactions and evaluate the risk-benefit balance of using non recommended ARV in coinfected patients with advanced hepatic disease.

\footnotetext{
Authors' details

${ }^{1}$ Timone Hospital, Pharmacokinetics and toxicology department, Marseille France. ${ }^{2}$ AP-HM Conception Hospital, Infectious Diseases department, Marseille, France. ${ }^{3}$ Pays d'Aix Hospital, Hematology and Internal Medicine Department, Aix-en-Provence, France. ${ }^{4}$ AP-HM, Hôpitaux Sud, Medicine in prison department, Marseille, France. ${ }^{5}$ Sainte Musse Hospital, Infectiology
} 
department, Toulon, France. ${ }^{6}$ AP-HM Conception Hospital, Digestive surgery department, Marseille, France. ${ }^{7}$ European Hospital, Marseille, France.

${ }^{8}$ Alphabio Laboratory, Marseille, France. ${ }^{9}$ AP-HM Sainte-Marguerite Hospital, Immuno-Hematology department, Marseille, France. ${ }^{10}$ University of Aix-

Marseille, INSERM UMR 911 - CRO2, Faculty of Pharmacy, Marseille, France.

Published: 23 May 2014

doi:10.1186/1471-2334-14-S2-P83

Cite this article as: Chantry et al:: Boceprevir (BOC) and Telaprevir (TPV) therapeutic drug monitoring in HCV and HIV-HCV infected patients treated with triple therapy Ribavirine/Peg-interferon/Boceprevir or Telaprevir: impact of the antiretroviral (ARV) treatment. BMC Infectious Diseases 2014 14(Suppl 2):P83.

Submit your next manuscript to BioMed Central and take full advantage of:

- Convenient online submission

- Thorough peer review

- No space constraints or color figure charges

- Immediate publication on acceptance

- Inclusion in PubMed, CAS, Scopus and Google Scholar

- Research which is freely available for redistribution

Submit your manuscript at www.biomedcentral.com/submit
C Biomed Central 